\title{
Muse and Power: African Women Writers and Digital Infrastructure in World Literature
}

\author{
Paula Uimonen \\ Department of Social Anthropology \\ Stockholm University, Sweden
}

SUMMARY This article explores how women writers in Nigeria and Tanzania use digital media, drawing parallels between infrastructural enablement and literary worldmaking. It argues that female African writers offer insights into the embodied practices and cultural imaginaries of digitally mediated creativity, which can shed light on the paradoxical entanglements of infrastructure. [infrastructure, world literature, African women writers, digital media, worldmaking]

Luckily electric power came back just in time for Zuhura Seng'enge's first poetry launch, a collection entitled Warrior Unleashed (Seng'enge 2016). The launch took place on July 15, 2016, at Soma Book Café, one of the few urban spaces dedicated to literature in Dar es Salaam, Tanzania (Figure 1). Her performance poetry required an advanced technical set up, with a computer-based sound and light system. In case of power failure, she would have had to make do without the accompanying digital music, the microphone and speakers that amplified her voice, as well as the ambient electric light that delineated the small platform in the garden that served as a stage. While Zuhura busied herself lining up upholstered chairs in neat rows, the technicians set up the light and sound system. But they could only check the system in the last minute, when electricity finally returned after a few hours of power outage due to some repair work in the neighborhood. Zuhura did not seem worried, after all power came back as scheduled, while its temporary absence was a common occurrence, to be improvised around.

Like writers in other parts of the world, female writers in Tanzania and Nigeria rely on digital infrastructure for their literary practice. Indeed, similarly to academia and other creative professions, digital media has evolved into a critical infrastructure in world literature, enabling the production, circulation, and consumption of literature worldwide. In the case of the performance poet Zuhura, her innovative literary expression is digitally mediated in multifaceted ways. But even the production of printed books requires digital infrastructure, as do other aspects of literary creation. In light of its growing significance, it is worth exploring how digital infrastructure plays out for writers in different parts of the world.

This article interrogates the interplay of electricity (power) and creativity (muse) in the literary practices of contemporary female African writers in order to tease out some of the paradoxical entanglements of digital infrastructure and world literature. ${ }^{1}$ Based on onsite interviews and online interaction with a

Anthropology and Humanism, Vol. 44, Issue 1, pp 20-37, ISSN 1559-9167, online ISSN 1548-1409. (C) 2019 by the American Anthropological Association. All rights reserved.

DOI: 10.1111/anhu.12236. 


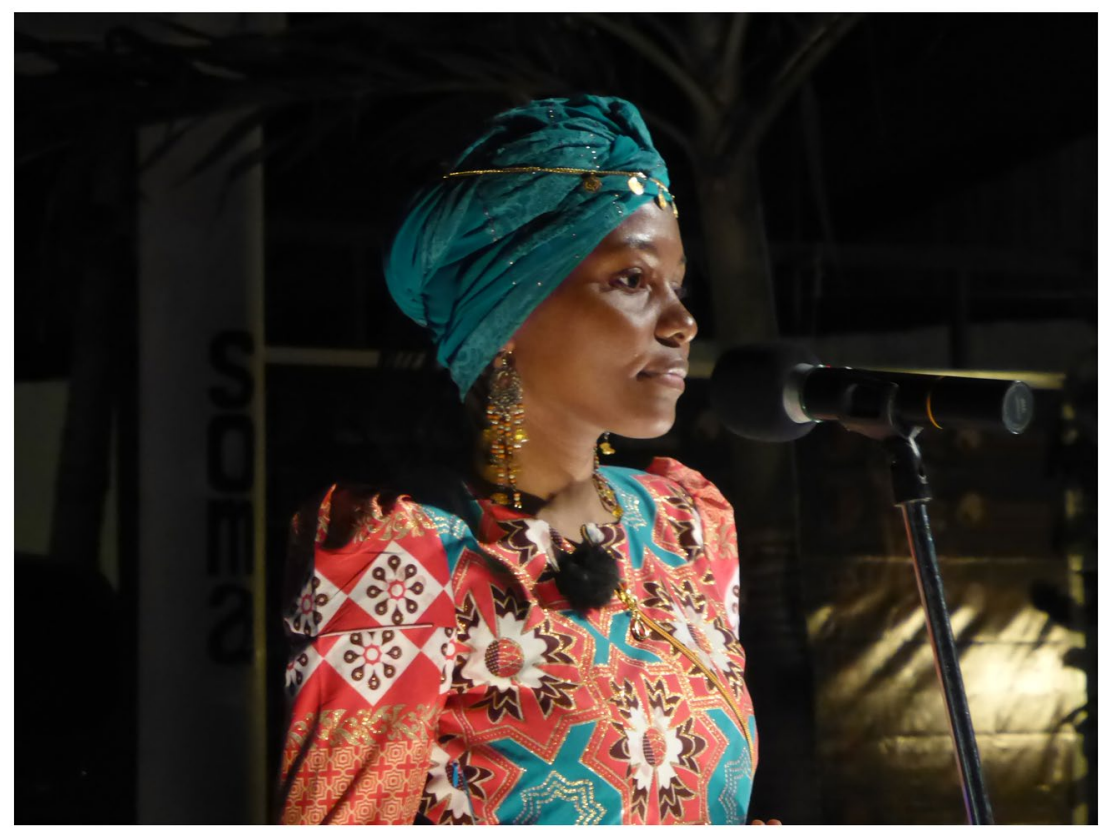

Figure 1.

Zuhura's poetry launch at Soma Book Café. [This figure appears in color in the online issue.]

select number of writers in Tanzania and Nigeria (2016-2018), the article offers some empirical insights into digitally mediated literary crafting. ${ }^{2}$ Theoretically, the article aims to make a contribution to current anthropological debates on infrastructure (Larkin 2013; Anand et al. 2018), especially electricity (Anusas and Ingold 2015; Boyer 2015, 2016; Howe et al. 2016), by way of digital media in African literature (Nesbitt-Ahmed 2017; Uimonen 2018) and world literature studies (Cheah 2014; WReC 2015). Looking at the enabling and mediating capacities of digital infrastructure, it argues that the literary worldmaking of female African writers offer analytical insights into the embodied practices and cultural imaginaries of digitally mediated creativity, thus drawing on art and literature to broaden the scholarly understanding of infrastructure.

\section{African Literature and Digital Potential}

The potential of digital media for African literature has been estimated to be nothing less than revolutionary, as exemplified by a recent scholarly article, which suggests that a "quiet literary revolution' is happening alongside a digital revolution" (Nesbitt-Ahmed 2017:378). Focusing on online literary platforms, Nesbitt-Ahmed explores literary opportunities such as online publishing, mobile interfaces, and multilingual publishing, concluding that new technologies are "enabling" writers and readers of African literature to "reclaim" and "reframe" their "own narratives" (ibid.:387). African writers have also reflected on digitally mediated transformations. In his keynote address at 
the Forty-First African Literature Conference in 2015, the Nigeria-born writer Teju Cole mused on African digital futures. Thought-provokingly entitled, "Do African digital natives wear glass skirts?" his keynote dwelled on emerging generations of "African digital natives," the glass skirt metaphor referring to "how much of our lives, 'even' on the African continent" is happening through the interface of touchscreens (Cole 2017:39-40). By comparison, some years earlier the Tanzanian female playwright Amandina Lihamba predicted that "the growing use of computers and information and communications technology (ICT) added to the belief that voices of African writers, including those of women writers, would increase in volume and variety" (Lihamba 2009:x). She noted however that with the exception of a few initiatives, these "gaps await to be filled" (ibid.).

Predictions of revolutionary change are instructive of the potential of digital media, capturing the enabling essence of infrastructure, which has been defined as "matter that enable the movement of other matter" (Larkin 2013:329, emphasis added). Indeed, discourses on digital potential elucidate the poetics and aesthetics of infrastructure. In the case of digital infrastructure, the "poetic mode" of infrastructure whereby "form is loosened from technical function" (ibid.:335) is evident in the emphasis on sociality over materiality, through discourses on communication, interaction, and networking, as opposed to cables and computers, with social media being an illustrative example. When it comes to the aesthetic dimension of digital infrastructure, which Larkin analyses in terms of "sensory apprehension of existence" (ibid.:338), there is something to be said for the ubiquity and embeddedness of digital media in everyday life. Perhaps the most poignant example of the sensory aesthetics of digital infrastructure is the mobile phone, which functions like a material extension of the self (Uimonen 2015). Indeed, scholars have noted the visual materiality of mobile infrastructure in different African contexts, a ubiquitous feature in urban and rural landscapes (e.g. Archambault 2012; Uimonen 2015), as well as everyday communication, interactions, and transactions (e.g. de Bruijn et al. 2009; Maurer et al. 2013; Stark 2013). In many places on the African continent, everyday life is thus experienced in environments that embody and express the poetic potential of digital infrastructure.

The poetics and aesthetics of digital infrastructure can be compared with art and creativity. In an effort to go beyond aesthetics, Gell has defined art as a technical system and art objects as technologies of enchantment (Gell 1992). While his definition asserts the materiality of art, along with a more relational approach that emphasizes the social agency of art objects (Gell 1998), it underrates the cultural imaginaries of technical systems, an aspect that art shares with infrastructure. As Larkin notes, infrastructures "operate on the level of fantasy and desire," encoding "the dreams of individuals and societies," thus forming us as subjects through the "mobilization of affect" (Larkin 2013:333). This is comparable to the enchantment of art-its magic, which touches and moves us, mediating our individual and socially shared experiences of life. Yet, this social process is not just a question of people and their social relations being "mobilized by technologies" (ibid.) or by the "products of techniques" (Gell 1992:43). Art like infrastructure also plays out in the imagination, which has to do with creativity, a generative and relational process of worldmaking 
encapsulating a sense of being in the world that is always in the process of becoming rather than ready-made through constant cultural improvisation (Hallam and Ingold 2007).

In digital anthropology, the virtual and the digital are ultimately cultural, a postulation with direct bearings on infrastructure. Virtual worlds are just as real as physical worlds, but they are digitally mediated and thus distinguishable from the actual world (Boellstorff 2008). Online worlds are, of course, socially created and inhabited, which is why the virtual, in the philosophical sense of "as if" and "almost," is cultural (ibid.:19). Similarly, the digital is a form of mediation, its cultural essence predating digital technology (Horst and Miller 2012). Comparatively, the poetic mode of infrastructure creates a "politics of 'as if'," which generates an "aesthetic order" where symbolic meaning and visual representation can be more significant than the material infrastructure itself, which may or may not exist or function (Larkin 2013:335). This virtual aesthetic order is culturally embedded in digital infrastructure, which from the outset has generated utopian visions of societal change, along with dystopian predictions of social relapse, in polemical discourses that have accompanied the global development of the Internet (Uimonen 2001). Indeed, hyperbolic notions of technology-induced social change run deep in cultural imaginaries of modernity.

If we focus on cultural worldmaking we can draw some interesting parallels between infrastructure and literature, especially literary worldmaking. It is quite common in world literature studies to focus on the global circulation of literature, thus foregrounding global capitalism in literary production. World literature has even been conceptualized as a world-literary system, with an emphasis on uneven and unequal development (WReC 2015). This materialist orientation has been challenged for its negligence of cultural imaginaries (Cheah 2014). Building on Cheah, we can explore literature in terms of literary worldmaking: literature not only gives meaning to the world, but it can also "enact the opening of a world" (ibid.:324). Cheah even suggests that the world has "a 'literary' structure," in an "infrastructural" sense, because it is created through narratives.

Returning to the potential of digital infrastructure and African literature, we can approach this from the perspective of digitally mediated literary worldmaking. Digital infrastructure evokes fantasies of modernity and desires of belonging in the world. While its material basis is emblematic of the political economy of global capitalism, the imaginaries of digital infrastructure go well beyond such structural constraints, opening up new worlds in the making. Digital infrastructure can thus be imagined as an enabling force for the production and consumption of African literature (Nesbitt-Ahmed 2017), bringing forth the voices of marginalized female writers (Lihamba 2009). Using literary imagination, digital infrastructure can even be rethought in more human terms, as Cole's suggestive conceptualization of Twitter as a city (Cole 2017). In these examples we see the virtual aesthetic ordering of potential, imaginaries of the "as if" of digital infrastructure; expectations of a future and reinterpretations of the present in a digitally mediated world in the making. It would thus seem that digital media not only enable literary creativity, but it also offers a material infrastructure for the making and remaking of the world. 


\section{Female African Writers and Digital Practices}

Zuhura Seng'enge launched her second poetry collection Love Blooms online on December 30, 2017, a release she announced through her social media accounts: WhatsApp, Twitter, Instagram, and Facebook. Unlike her first collection, which she published on compact disc, the second collection was only published on the Internet, through SoundCloud, an online audio platform (Seng'enge 2017). A few days before the launch date, Zuhura posted the cover image of the collection on Facebook (Figure 2), announcing: "\#THREE DAYS left to release date. Here is \#LoveBlooms, track no. 6. Enjoy the rest of the week!" When the collection was launched she posted the cover image on Instagram: "LOVE is Blooming on the Cloud of Sounds. It's a \#poetry audio anthology by yours truly. @zu_the_africanlioness."

Zuhura's online publication of poetry is instructive of the growing significance of digital media on the African literary scene, especially among younger writers who seize the potential of digital infrastructure for their literary activities. Having grown up with digital media, these young writers belong to what

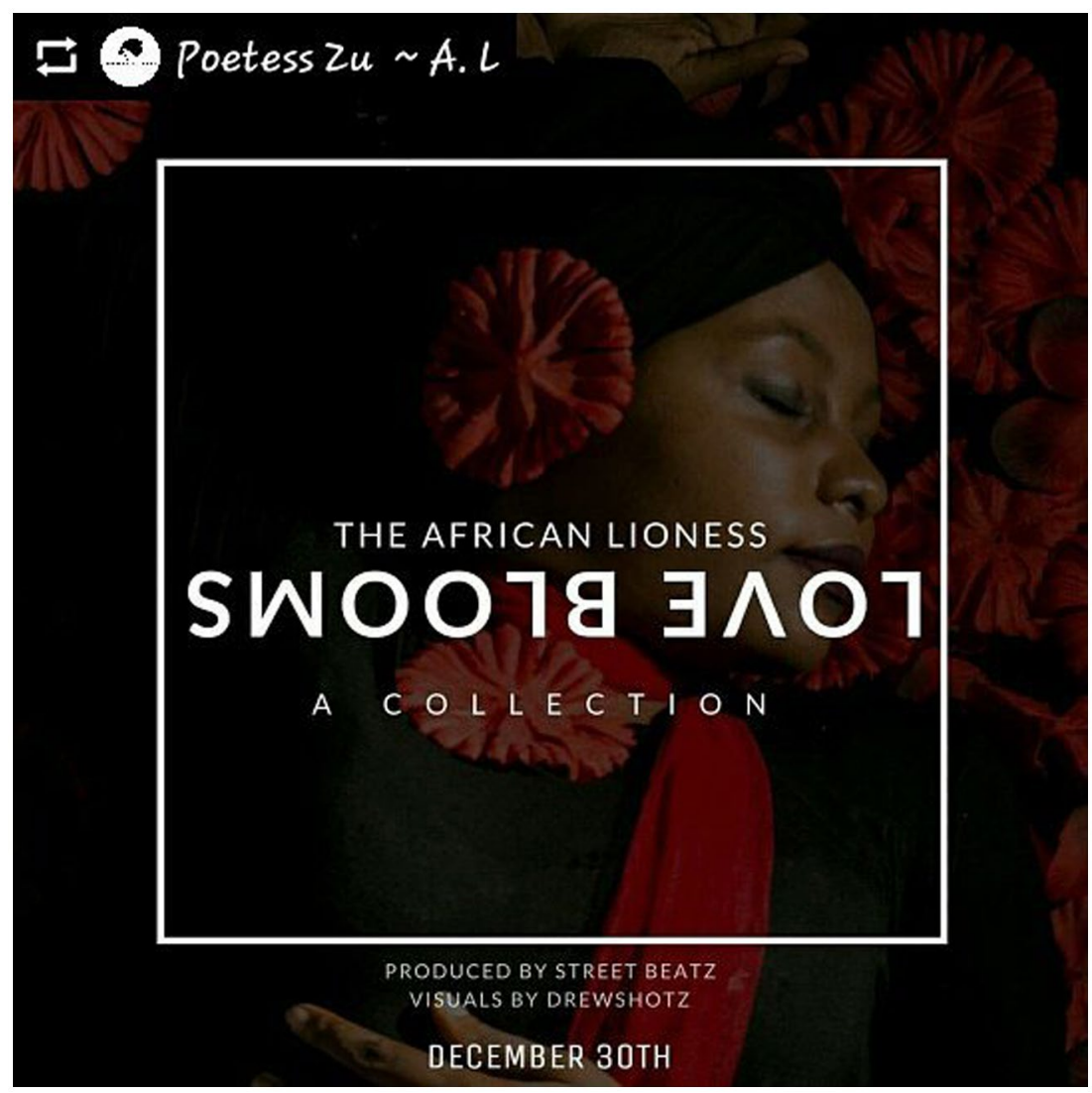

Figure 2.

Online publication of Love Blooms. [This figure appears in color in the online issue.] 
Cole described as African digital natives (Cole 2017). Their everyday lives are mediated through touchscreens, not least smart phones, which they use to research materials for their writings as well as to publish and promote their literary work. Through social media such as Facebook and Twitter, they can establish and maintain social networks of collaborators and supporters while reaching out to their readers as well as other writers. Paraphrasing Cole, it should be noted that these digital practices are commonplace among writers even in Tanzania, a country with a rather minute literary scene and a peripheral positioning in the global network society (Uimonen 2012).

In Zuhura's case, we can see digitally mediated multilingualism at work, her poetry collections being bilingual in English and Kiswahili. Given the linguistic diversity of the African continent, with over 2,000 Indigenous languages, it is no surprise that the potential of digital infrastructure is assessed in relation to language, as it "enables a literary community centered on indigenous languages to be built," thus "opening up more opportunities" for African writers as well as readers (Nesbitt-Ahmed 2017:387). Similarly, the ability to connect writers and translators around the continent can facilitate the translation of African literary works into other African languages as well as into English (ibid.:385). In Zuhura's case, her literary production is bilingual from the outset. Like many other contemporary women writers in Tanzania, her preferred language is English, which is a prerequisite for reaching out to international audiences, because few works get translated from Kiswahili. But she also uses Kiswahili, which is one of the most used African languages, spoken in many parts of East Africa and beyond, and an essential feature of the Tanzanian national identity.

Zuhura combines different media and artistic genres in her aesthetic performances. I have elsewhere discussed her creative combination of orature, literature, theater, and music in terms of a transnational tangle in literary production, drawing on cultural strands of various spatiotemporal origin (Uimonen 2018). Since the launch of her first poetry collection in 2016, Zuhura has formed "The Conscious Band," a trio (Zuhura with two musicians) that performs together. Her poetry has evolved in a more musical direction, at times resembling songs (ballads or raps) rather than poems, but she remains passionate about poetry. Thus, her second collection, Love Blooms, starts with the track "Love affair with words," a tribute to poetry. Using different media, Zuhura's performance poetry relies on digital infrastructure, combining audio and audiovisual technology with social media.

Digital infrastructure has become a common feature in poetry events in Dar es Salaam, from online promotion to staged poetry recitals. Poetry groups such as La Poetista, Waka Poets, and Poetry 255 rely on social media to announce upcoming events and to attract audiences, often through posters designed for the specific event, distributed online as images. Audience members are often asked to sign up at the event, sharing their contact details such as phone numbers and email addresses for future communication. During events, organizers often take photos, which they post on social media, and audiences are encouraged to do the same, using shared hashtags. After the event, the organizers typically thank people for participating and post some photos online as memories of the event. At poetry events, poets who recite poems often read them off 
their smart phones. For instance, Lydia Kasese, a young published poet (Kasese 2016), stores her poems on her smartphone. Although she does not like to perform in public, she sometimes recites a poem by reading it off her smartphone screen. Lydia also publishes some poems on her blog, announcing releases on her Facebook page.

Writers also rely on digital infrastructure for writing and editing, as exemplified by Razinat Mohammed, a writer in Maiduguri, northern Nigeria. ${ }^{3}$ Razinat holds a PhD in feminist literary criticism and gender studies from University of Maiduguri (UNIMAID), where she works as a lecturer. She writes poems, short stories, and novels. Her first short story collection (Mohammed 2006) won the ANA Award (Association of Nigerian Authors) and her second book, Habiba, was one of three shortlisted best novels for 2014 (Mohammed 2013). More recently she published The Travails of a First Wife (Mohammed 2015), a novel that addresses jealousy, suspicion, and hatred among women in a polygamous household. Even before I met Razinat in Maiduguri, we had connected through email and she often responded quickly, within hours. During our interview in Maiduguri, we talked about her digital writing practices:

Paula: How do you use digital media for your writing and reading? I mean computers, Internet, mobile phone, all.

Razinat: I type directly on the computer. I do my editing, I do my scripting, I do my proof readings there. But often I transfer them to my phones. All my books are on my phones. All my works actually, I have them on my phone. The unpublished ones, maybe in the plane, in the car travelling ... if an idea occurs to me, because they are not published, I can open my phone, edit it, add something or subtract something, and then save and continue.

Paula: So you can edit on your phone?

Razinat: I do! Because I have a Microsoft phone. My phone is Microsoft. [shows me her two phones] I have 2 Mega on this, this I don't edit in, but here I edit, because it is a Microsoft. It has an Office. So all the Windows, it is a Windows phone. So I am able to edit everything here and save. If you just open it, just like my computer. I am not a fan of iPads. I don't know why, because as a creative writer, I need a keyboard. I can only edit on the phone. But as a creative writer, I need a real keyboard, to type my work directly with my fingers. But when I am editing, I can do the punching.

Razinat's reliance on computers and mobile phones is instructive of how digital infrastructure is transforming the embodied practice of writing. In her case, writing means typing with her fingers on a keyboard rather than putting a pen to paper. Interestingly enough, Razinat also edits her work on her mobile phone, punching instead of typing. By keeping all her works on her phone, and even editing unpublished ones on her phone when she gets an idea, Razinat has integrated digital media into her writing practices, the smart phone in particular, making her creative writing a digitally mediated embodied practice.

There is some variation in the extent to which writers rely on digital media, depending on timing as well as habit. Elizabeth (Lizi) Ben-Iheanacho, a writer and folklorist based in Abuja, the capital of Nigeria, used to write on "bits and pieces of paper," which she went through when composing a story. ${ }^{4}$ These days 
she uses Facebook, where she posts her "creative ideas, whatever they may be, in a flash of poetry or prose," some of which she uses for stories. When asked how she uses digital media, Lizi responded: "These days you really have no option." She writes on a computer and publishes on Facebook, mostly though her mobile, which she calls her "Facebook workshop." She does "more serious" work on her laptop, compiling and editing stories, while the mobile is "more instantaneous," an interface for "pieces of flying, creative things," which she then puts together on the laptop. Eugenia Abu, a well-known Nigerian media professional and a writer talented in all genres, prefers to write on paper. She likes to write early in the mornings and uses a simple ballpoint pen on unlined A4 paper. $^{5}$ She types her work on a computer but prefers writing on unlined paper because "it flows better" with no "obstacles."

Writing practices are shaped by creative flow, directed by the muse rather than the mouse. Writers often told me that they write when the muse sets in, which is also why the mobile is a useful device, always within reach. In this sense, the mobile phone functions as a material extension of the creative writer, a multisensory device for inspired self-expression. In response to the question when and where do you write, Lizi responded "anytime, anywhere." She explained: "Sometimes the muse grips you, a story just sits on you. It's a heavy load on your chest. And it says to you: 'if you don't put me down, you are doing nothing else."' Whenever inspiration sets in, the writer will thus reach for an outlet, a piece of paper, or a laptop, or a smartphone, depending on what is available and accessible.

Writers read a great deal and the reading is sometimes done through digital media: computers, iPads, or smart phones. Unlike her children who are online 24/7 and quite used to "digital reading," Lizi prefers printed books: "For me a book is that hard copy," she reflected, gesturing as if touching a book. Lydia on the other hand carries e-books with her at all times, reading them on her smartphone or iPad. Variations in digital reading habits are undoubtedly attributable to age, as younger generations are more used to it. Even so, all writers that I have interviewed edit their work on a computer, thus reading on a screen.

\section{Online Publishing and Networked Events}

Digital infrastructure offers new channels for publishing literature. It has been noted that online publishing "disrupts existing structures," while creating new structures that cater to "the growing number of digital natives," thus making the publishing industry "a lot more accessible" (Nesbitt-Ahmed 2017:379-80). While traditional publishing companies have been slow in adopting new technologies, new publishers have emerged, a notable example being Cassava Republic Press based in Nigeria (Nesbitt-Ahmed 2017; Stringer 2016). By distributing books online for African audiences, and developing new genres that cater to younger readers (e.g. romance and science fiction), these "nimble, creative and experimental publishers" are said to be "breathing new life into African publishing" (Stringer 2016:195). South African Cover2Cover Books has even published short stories on mobile phones (ibid.:197). I have not yet come across a writer who uses these new outlets, but several of the writers interviewed have opted for transnational publishing and self-publishing. 
Through digital media, writers can publish their works through transnational outlets. For instance, writer and interior designer Sandra Mushi, based in Dar es Salaam, published her second collection of poetry and short stories, Stains on my Khanga (Mushi 2014), through the South African outlet Hadithi Media rather than a local publishing house. ${ }^{6}$ The young Nigerian writer Gertrude Uzoh self-published her debut novel, One Love, Many Tears: It Takes Two to Tango (Uzoh 2012) through the U.S.-based AuthorHouse. Transnational publishing requires digital infrastructure, because writers send their manuscripts and communicate with their publishers online, while distribution combines digital and material processes, with books printed on demand or sold as digital versions.

Self-publishing exemplifies digitally mediated self-making, an important aspect of the creative worldmaking enabled by digital infrastructure. Boellstorff (2008) has argued that online virtual worlds signify the rise of techne (crafting) over episteme (knowledge), with new forms of self-making. In literary production, self-publishing enables writers not only to distribute their works, but in so doing they become published authors. Through digitally mediated self-making, writers can thus earn cultural capital, their financial investment paying off in more eminent forms of selfhood. This shows how infrastructure can "function as a form of capital that interacts with other forms of capital," more specifically how "Internet communication technologies, draw from and expand social and cultural capital" (Howe et al. 2016:552). Even so, a self-published author does not necessarily carry the same status as a published writer, and it takes much more than publishing to become a recognized writer.

Networking and promotion are important aspects of digitally mediated self-making. Through social media writers can establish and develop their cultural identity as creative writers. Online publication and promotion can augment their social status, embedding their literary self in social networks of recognition (cf. Wulff 2017). Digital media can also expand writers' fame, reaching readers and collaborators in different parts of the world. In our first interview on July 4, 2016, Zuhura noted that she had 439 followers on her Facebook page, which to her signified "people who have been inspired and interested in the page." Through Facebook and Twitter she could "share with other writers, Africans and outside Africa," not least by sharing links to their stories online. This ability to network with readers and writers is an important aspect of literary practice, interactions, and exchanges that affirm the social embeddedness of art objects while enhancing the social agency of artists.

Digital infrastructure can also enable the creation of online art spaces, exposing and connecting writers, while offering a sense of transnational community. When I first met Zuhura, she was one of twelve participants in the Flow Workshop of Short Story Day Africa in Dar es Salaam, facilitated by Sandra Mushi. Workshops were organized in seven different cities in Africa, on June 18 and 25, 2016. The one in Dar es Salaam took place on the same day as a workshop in Addis Ababa. Calls for applicants had circulated online, and attendees were selected based on their online submissions. I was struck by the ubiquity of digital devices at the workshop, and I also noted that different hashtags were placed on the tables, signifying the event and linking the workshop to online networks (Figure 3). Participants had their smart phones on hand at all times, 


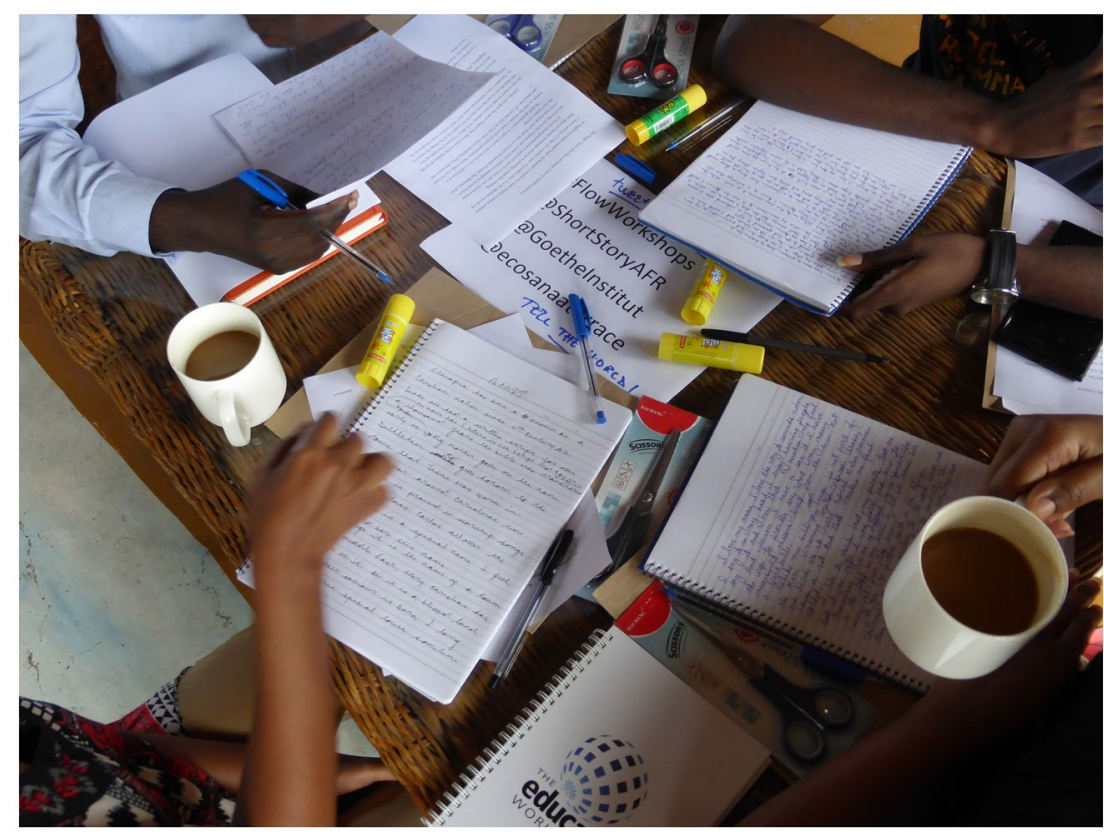

Figure 3.

\#FlowWorkshop in Dar es Salaam. [This figure appears in color in the online issue.]

while the facilitators moved around with an iPad and a digital camera taking photos and posting updates on social media. Throughout the day, organizers and participants shared highlights and images on Twitter, using the hashtag \#FlowWorkshops, as did their counterparts in Addis. Through Twitter, the workshop was thus recreated as an online art space that mirrored the workshops in Dar and Addis while being accessible to interested parties online, regardless of their physical location.

Literary events such as festivals, competitions, and awards are also digitally mediated, attracting writers, readers, critics, scholars, publishers, and literary agents. These literary events are becoming more commonplace on the African continent, replacing book fairs (Stringer 2016) while giving renewed visibility to literature (Nesbitt-Ahmed 2017). There is, however, considerable variation; Nigeria has several major literary events every year, while Tanzania has yet to host a literary festival. Over the last few years, I have participated in three major literary events: FEMRITE@20, Efuru@50, and the Continental Colloquium of the Pan-African Writers' Association (PAWA). ${ }^{8}$ FEMRITE@20 and Efuru@50 were organized at universities, affirming the linkages between academia and literature, while the PAWA colloquium took place in a five-star hotel. The events featured keynote speeches by esteemed literary scholars and writers; analytical papers by scholars and writers; artistic performances of poetry, drama, and music; as well as festive dinners and receptions (Figure 4).

These events were organized and promoted online, through web sites, social media, and email, and attracted considerable media coverage from broadcast 


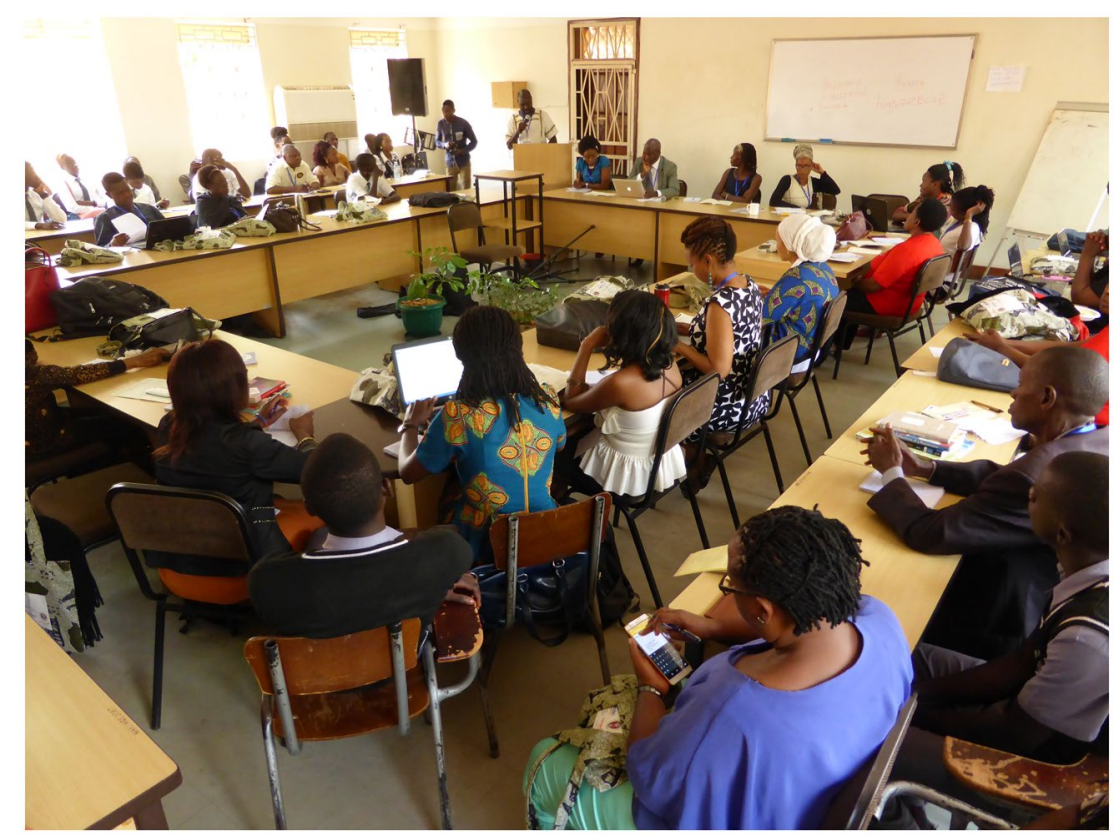

Figure 4.

FEMRITE@20 in Kampala. [This figure appears in color in the online issue.]

and print media, especially when attended by high level political dignitaries such as the President of Ghana at the PAWA event or the Deputy Governor of Enugu at the Efuru@50 event. Participants ranged from 150 to 700 people, with mostly national and regional presenters and primarily local audiences, along with a few international attendees. In literary events devoted to female writers, there were more female than male attendees. The events were highly ritualized, with elaborate protocol, eloquent tributes and promotional paraphernalia, and participants dressed up in elegant gowns and shirts, many of locally tailored design. These literary gatherings certainly gave the impression of the cultural significance of literature, but it is not clear to what extent they have a durable impact beyond the social circles of cultural elites.

\section{Digital Disruptions and Structural Constraints}

"Not enough power sometimes, electricity, because I mean when the muse gets you, you got to write, and if you don't have a generator and there is no power, then that's hard," Eugenia Abu responded when asked about the main challenges for writers in Nigeria. I was surprised when several of the female writers I interviewed in Nigeria mentioned electricity as a challenge to writing. While illustrating the extent to which their writing practices have become digitally mediated, their concerns about electricity spoke to the frequency of power disruptions, which interfered with the creative force of the muse. Power outages highlighted some gaps that wait to be filled, namely "the gap between 
actual and potential," between "what technologies can do and what they do do" (Larkin 2008:235, emphasis in original).

Digitally mediated creative writing hinges on functioning infrastructure, especially electricity, which cannot be taken for granted. I have argued elsewhere that the scholarly assumption that infrastructure is invisible until it breaks down simply does not hold in many African contexts where malfunctioning is the norm, not the exception, despite the material ubiquity of digital infrastructure (Uimonen 2015). In urban Nigeria, the "ubiquitous experience of breakdown as a condition of technological existence" has been well documented (Larkin 2008:234). It is telling that the Nigerian Electric Power Authority is colloquially known as Never Expect Power Always, but even when there is power "electricity supplies are unreliable" (ibid.). In urban Tanzania, the situation is somewhat better, but the unreliability of electricity has been discussed in terms of an aesthetic of infrastructure characterized by permanent improvisation (Degani 2018).

Malfunctioning systems point to the partial presence of electricity infrastructure (Gupta 2015), or what I have elsewhere described as partial inclusion in the global network society (Uimonen 2012). Although electrification in places such as Zanzibar can bridge the gap between center and periphery (Winther and Wilhite 2015), it does not erase structural inequalities. While there is considerable variety in electricity supply on the African continent, recent research has shown that most countries in Sub-Saharan Africa have inadequate supply and frequent shortages (Farquharson et al. 2018). In Nigeria, 56.4 percent of the population has access to the electricity grid, but the country tops the list of annual outage hours with 4,600 hours. Only 18.9 percent of Tanzanians have access to the grid, with 670 hours of outage annually. By comparison, in Kenya, 36 percent of the population is connected to the grid, with 420 annual outage hours. South Africa, the most well connected country, provides grid services to 86 percent of the population, with only 50 hours of outage (ibid.:590). This shows that while there is considerable variation, large parts of the African continent are still underserved with electricity grids, while supplies tend to be unreliable.

Malfunctioning digital infrastructure interferes with the temporality of creativity, disrupting moments of creative flow. No matter how strong the force of creativity, inspiration may not coincide with the availability of electric power. In daytime, if batteries are sufficiently charged, mobiles and laptops can still be used, and Internet connectivity may still be available, because mobile operators have alternative power supplies. But night time infrastructural malfunctioning is more disruptive, because it also means the absence of light, which is a critical feature of electric infrastructure (cf. Gupta 2015; Winther and Wilhite 2015). Most female writers I have talked with write late at night or early in the morning, because their daytime hours are usually filled with professional work and attending to family and other social relations. It is during quiet, undisturbed hours at home that they can indulge in their creative work when others are asleep. Infrastructural malfunctioning can thus disrupt and impede already existing spatiotemporal limitations, not least for female writers.

The digital infrastructure of self-publishing sheds further light on structural constraints of literary crafting. While self-publishing opens new opportunities 
for creative self-making, it places more demands on the writer, consuming time, effort, and money. As Lizi reflected in an interview:

The challenge is, having battled with your muses, and having wrestled all of those thoughts into some form of creative expression, how do you get published? Who publishes you? Who gives you visibility as a writer? And we know that as long as that mystical visibility is denied your creative work, you are as good as dead as a writer. So you have a lot of self-publishing going on [...] It's an arduous task for you to be a writer, your own publisher, your own marketer, your own critic.

The self-published writer can be described as "touts in the literary market," as Lizi succinctly put it, self-promotional actors in a competitive market where "everyone proclaims themselves to be the best and the greatest, even before you have seen a copy of the book." Creative self-making is expressive of the workings of global capitalism, turning creative writers into self-funded and self-promotional neoliberal subjects in a global literary market. In an African context, the unevenness of this literary world system is quite palpable (WReC 2015). While hawking their own books can be a way to establish themselves as published authors on the local or national literary scene, breaking into the international market is a daunting task. "I don't know the platform that we have these days to compete externally," Lizi noted. "African Writers series used to do that for African writers, both the upcoming and established writers, because that was the canon-forming body." The canonical Heinemann series was sold to a smaller publisher some years ago, rendering it much less influential. "So who is publishing the African writer?" she said.

Self-publishing is also a risky affair with little financial gain. While it offers the writer the freedom to publish, it also dislodges the literary work from established channels of quality control. Moreover, much of the burden of distribution rests with the author, making the commercial success of self-publishing uncertain at best. Many of the writers I spoke with lamented the lack of reading culture, let alone book buying culture, which has hampered the development of the literary scene in Africa, long before the advent of digital media (cf. Griswold 2000). Textbooks continue to be the primary source of income for most publishers, and they typically avoid the risk of publishing fiction (Stringer 2016). Some writers opt for a hybrid model, where they pay for publication through a wellknown publishing house. While this option can offer better quality assurance, it does not guarantee commercial viability. Through self-publishing, individual writers thus shoulder the risks of the commodified market of the world literary system, without necessarily drawing financial benefits.

Online publishing captures the cultural significance of digital potential, as exemplified by Zuhura's efforts to develop her career. When she released her second collection, Love Blooms, online, Zuhura explored a new way of developing her career, which she reflected on in terms of "trial and error." ${ }^{\prime 9}$ Although she managed to sell all 100 copies of her first collection on compact disc, she noted that most people listen online. Through SoundCloud, she can keep track of how many people actually listen to her poems, which within a few weeks of release already was some 200 people. Her strategy is to create awareness of her poetry through various online activities, thus creating a network of followers. 
In addition she plans to create videos of her poems and sell them on DVDs. She compared her situation to the music industry, noting that musicians primarily make money from endorsements and performances, while releasing their songs for free. Similarly, Zuhura aims to create a name for herself, which then can lead to other forms of sponsorship and money-making projects. Indeed, Zuhura's creative self-making relies on the potential of digitally mediated fame.

\section{Divine Inspiration and Worldmaking Infrastructures}

Lizi is praying to her mobile phone, pleading for faster network access so she can transfer the money her son is waiting for. We are sitting by the poolside of my hotel in Abuja, far from the noise of the generator that is supplying electricity during the power outage. The mobile network is slow, so Lizi's transfer takes a while. Once completed, she relaxes, and we continue our spirited conversation. It is July 23, 2018, and I have just returned to Nigeria to go through my draft manuscript with the writers who feature in the monograph (Uimonen 2019). Since we last met in December 2016, Lizi and I have stayed in touch through Facebook, and having followed her daily postings for so long, I feel as if I know her quite well. We both giggle at Lizi's prayers; her invocation of spiritual power to counter digital shortcomings makes perfect sense, complementing her daily postings of religious messages in Facebook. In a deeply religious society such as Nigeria, God is invoked in all kinds of circumstances. Lizi's prayers also remind me of anthropological work on electricity in Nigeria, which has looked at infrastructure as a divination tool (Trovalla and Trovalla 2015).

As discussed earlier, anthropological analyses of infrastructure, especially electricity, underline its enabling capacity. Building on Larkin's definition "[i] nfrastructures are matter that enable the movement of other matter" (Larkin 2013:329), Boyer suggests that the "enabling power of electricity" makes it an "infrastructure par excellence," a system of mediation through which we can rethink "power and enablement" (Boyer 2015:532). This emphasis on enablement points to the promise of infrastructure, especially in relation to its temporality, capturing aspiration, prospective, and futurity (Anand et al. 2018). Enablement has everything to do with cultural imaginaries; it is an infrastructural poetics of worldmaking that thinks of the world anew, challenging the world as is, conjuring other worlds.

Just like creativity, infrastructure is generative, mediating different ways of being in the world. Reflecting on how infrastructural systems interact in shaping certain subjectivities, Larkin notes: "Infrastructure in this sense is a kind of mentality and way of living in the world" (2013:331). I would extend this to ways of making worlds, a generative process that draws upon and augments cultural imaginaries. Digital infrastructure, which similarly to electricity offers new ways of thinking the world, is a case in point. Seeing that digital infrastructure requires electricity to function, it is no coincidence that these interdependent systems offer interesting insights into worldmaking. It has been suggested that "electrical wiring gives us a world that is more comparable to a woven textile" and that "the world is not so much built from blocks, as commonly supposed, as it is woven" (Anusas and Ingold 2015:550). This emphasis on "entanglements" and the perpetual "wiring of the world" could be used 
to describe digital infrastructure just as well as electricity. I have elsewhere discussed the entanglements of digitally mediated literary worldmaking in terms of a transnational tangle, building on a conceptualization of the world as a network of networks (Uimonen 2018). The notion of networked tangles is comparable with the idea that the material world consists of "knots or nodes in an energetic weave that crisscrosses different states of matter and life" (Anusas and Ingold 2015:549). But my interest here is not so much in the constitution of the material world as in how the world is creatively imagined.

If worldmaking is thought of in terms of weaving, we can draw further parallels between infrastructure and literature, because "text is a tissue of words" (Barber 2016:1). Noting that the word text originates in the Latin texere, which means to weave, to join together, Barber convincingly argues that text has to do with "weaving or fabricating with words" (ibid.). She looks at texts as social facts as well as commentaries on social facts, emphasizing the reflexive dimension of text in relation to social reality (ibid.:4). Building on Barber, we can thus affirm Cheah's suggestion that the world has a narrative structure, in an infrastructural sense, because text puts words on the weaving of worlds.

Through digital mediation, the textual weaving of worldmaking is extended in time and space, as literary imaginaries can reach a wider audience while offering commentaries on the diversity of social worlds that constitute the world in the making. The spatiotemporal mobility of literature, the way its woven worlds spread beyond original conception, is augmented by digital infrastructure, enabling its worldmaking potential beyond the materiality of objects, by mediating the movement of cultural imaginaries.

For female African writers, digital infrastructure thus offers yet another outlet for creative expression, weaving complex worlds with threads of divine inspiration. Embedded in daily life, digital infrastructure forms part of a way of being in the world that intertwines material, social, and spiritual dimensions (Uimonen 2019). These multifaceted entanglements are part and parcel of the poetics of infrastructural enablement, intrinsic to the power of the muse. So when Zuhura announced the upcoming launch of Love Blooms on Facebook and Instagram, she made sure to invoke divinity: "I thank Allah for the journey so far, and to me it seems only fitting as another chapter is ending, to close it with appreciation for the important pillars that build me and helped shape me. So brace yourself for \#LoveBlooms. New \#poetry \#collection coming out on the 30th of December."

\section{Concluding Remarks}

The power of the muse can be understood in an infrastructural sense as energy, a creative force that expresses the power of the imagination. Through the weaving of words, the power of the muse is transformed into cultural imaginaries of creative worldmaking. In this sense, infrastructure can be thought of as matter that enables the movement of cultural imagination, mediating a complex system of worldmaking. It has been suggested that any theory of infrastructure needs to be a theory of paradox, because it is in the "nodes of paradoxical intermingling and entanglement that we can rethink the complexity of infrastructure; its realization is only the limit of our collective imaginary" 
(Howe et al. 2016:559). If the realization of infrastructure hinges on our collective imaginary, it would seem that art and creativity offer productive entry points to unleash the power of the infrastructural muse.

\section{Notes}

1. I am grateful for the critique of two anonymous reviewers, whose comments have helped me sharpen the arguments in this article. I am also grateful to all the female writers who appear in this text for their comments on an earlier version of the article, via email or Facebook and during interaction in Nigeria in July 2018. The responsibility for any errors or omissions is of course mine only.

2. The article builds on the research project African Women Writers (see http:// www.womenwriters.one/), based on ethnographic fieldwork in Nigeria and Tanzania (2016-2018). The project is part of the multidisciplinary research program Cosmopolitan and Vernacular Dynamics in World Literatures (2016-2021), supported by The Swedish Foundation for Humanities and Social Sciences, see http://worldlit.se/.

3. Interview with Razinat Mohammed in Maiduguri on December 2, 2016.

4. Interview with Elizabeth Ben-Iheanacho in Abuja on December 12, 2016.

5. Interview with Eugenia Abu in Abuja on December 13, 2016.

6. Interview with Sandra Mushi in Dar es Salaam on July 21, 2016.

7. Interview with Gertrude Uzoh in Abuja on December 12, 2016.

8. FEMRITE@20 in Kampala in July 2016, the twentieth anniversary of the Ugandan women writers association; Efuru@50 in November-December 2016 in Nigeria, a celebration of the first internationally published novel by an African woman writer, Flora Nwapa's Efuru; and the Twenty-Fourth International African Writers' Day and Continental Colloquium of the Pan-African Writers' Association (PAWA) in Accra in November 2017.

9. Interview with Zuhura Seng'enge in Bagamoyo on January 26, 2018.

\section{References Cited}

Archambault, Julie Soleil

2012 “'Travelling while Sitting Down': Mobile Phones, Mobility and the Communication Landscape in Inhambane, Mozambique." Africa 82(3):393-412.

Anand, Nikhil, Hannah Appel, and Akhil Gupta, eds.

2018 The Promise of Infrastructure. Durham, NC: Duke University Press.

Anusas, Mike, and Tim Ingold

2015 "The Charge against Electricity." Cultural Anthropology 30(4):540-554.

Barber, Karin

2016 The Anthropology of Texts, Persons and Publics. Cambridge: Cambridge University Press.

Boellstorff, Tom

2008 Coming of Age in Second Life: An Anthropologist Explores the Virtually Human. Princeton, NJ: Princeton University Press.

Boyer, Dominic

2015 "Anthropology Electric." Cultural Anthropology 30(4):531-539.

2016 "Revolutionary Infrastructure." In Infrastructures and Social Complexity: A

Companion, edited by Penny Harvey, Casper Bruun Jensen, and Atsuro Morita, pp. 174-186. London and New York: Routledge.

de Bruijn, Mirjam, Francis Nyamnjoh, and Inge Brinkman, eds. 2009 Mobile Phones: The New Talking Drums of Everyday Africa. Langaa RPCIG.

Cheah, Peng

2014 "World against Globe: Toward a Normative Conception of World Literature." New Literary History 45(3):303-329.

Cole, Teju

2017 “Do African Digital Natives Wear Glass Skirts?" Journal of the African Literature Association 11(1):38-44. 
Degani, Michael

2018 "SHOCK HUMOR: Zaniness and the Freedom of Permanent Improvisation in Urban Tanzania." Cultural Anthropology 33(3):473-498.

Farquharson, DeVynne, Paulina Jaramillo, and Constantine Samaras

2018 "Sustainability Implications of Electricity Outages in Sub-Saharan Africa." Nature Sustainability (1):589-597.

Gell, Alfred

1992 "The Technology of Enchantment and the Enchantment of Technology." In Anthropology, Art, and Aesthetics, edited by J. Coote, and A. Shelton, pp. 40-63. Oxford: Clarendon Press.

1998 Art and Agency: An Anthropological Theory, Oxford: Clarendon.

Griswold, Wendy

2000 Bearing Witness. Readers, Writers, and the Novel in Nigeria. Princeton, NJ: Princeton University Press.

Gupta, Akhil

2015 "An Anthropology of Electricity from the Global South." Cultural Anthropology 30(4):555-568.

Kasese, Nyachiro Lydia

2016 Paper Dolls. Brooklyn, NY: Akashic Books.

Hallam Elizabeth, and Tim Ingold, eds.

2007 Creativity and Cultural Improvisation. New York: Berg.

Heather Horst, and Daniel Miller, eds.

2012 Digital Anthropology. Oxford: Berg.

Howe, Cymene, Jessica Lockrem, Hannah Appel Edward Hackett, Dominic Boyers, Randal Hall, Matthew Schneider-Mayerson, Albert Popoe, Akhil Gupta, Elizabeth Rodwell, Andrea Ballestero, Trevor Durbin, Farès el-Dahdah, Elizabeth Long, and Cyrus Mody

2016 "Paradoxical Infrastructures: Ruins, Retrofit, and Risk." Science, Technology E Human Values 41(3):547-565.

Larkin, Brian

2008 Signal and Noise. Media, Infrastructure, and Urban Culture in Nigeria. Durham, NC, and London: Duke University Press.

2013 "The Politics and Poetics of Infrastructure." Annual Review of Anthropology 42:327-343.

Lihamba, Amandina

2009 "Foreword." In African Women Playwrights, edited by Kathy Perkins, pp. 9-10. Urbana: University of Illinois Press.

Maurer, Bill, Taylor C. Nelms, and Stephen C. Rea

2013 “'Bridges to Cash': Channeling Agency in Mobile Money." Journal of the Royal Anthropological Institute 19(1):52-74.

Mohammed, Razinat

2006 A Love Like a Woman's and Other Stories. Ibadan, Nigeria: Kraft Books Limited.

2013 Habiba, Ibadan, Nigeria: Kraft Books Limited.

2015 The Travails of a First Wife. Lagos, Nigeria: Origami Books.

Mushi, Sandra Aikaruwa

2014 Stains on my Khanga, Centurion, South Africa: Hadithi Media.

Nesbitt-Ahmed, Zahrah

2017 "Reclaiming African Literature in the Digital Age: An Exploration of Online Literary Platforms." Critical African Studies 9(3):377-390.

Seng'enge, Zuhura

2016 Warrior Unleashed. Dar es Slaam: ijoh media group, CD.

2017 Love Blooms. https://soundcloud.com/zuhura-the-african-lioness/sets/ love-blooms.

Stark, Laura

2013 "Transactional Sex and Mobile Phones in a Tanzanian Slum." Suomen Antropologi: Journal of the Finnish Anthropological Society 38(1):12-36. 
Stringer, Roger

2016 "African Publishing in the Digital Age." In Coming of Age: Strides in African Publishing, edited by Kiarie Kamau, and Kirimi Mitambo, pp. 187-200. Nairobi: East African Educational Publishers Ltd.

Trovalla, Eric, and Ulrika Trovalla

2015 "Infrastructure as a Divination Tool: Whispers from the Grids in a Nigerian City." City 19(2/3):332-343.

Uimonen, Paula

2001 Transnational. Dynamics@Development.Net: Internet, Modernization and Globalization. Stockholm: Almqvist \& Wiksell.

2012 Digital Drama. Teaching and Learning Art and Media in Tanzania. New York: Routledge.

2015 "'Number not Reachable'. Mobile Infrastructure and Global Racial Hierarchy in Africa." Journal des Anthropologues (142/143):29-47.

2018 "Zuhura the African Lioness: Performance Poetry, Digital Media and the Transnational Tangle in World Literature." In World Literatures. Exploring the Cosmopolitan-Vernacular Exchange, edited by Stefan Helgesson, Annika Mörte Alling, Yvonne Lindqvist, and Helena Wulff, pp. 129-139. Stockholm: Stockholm University Press.

2019 Invoking Flora Nwapa: Nigerian Women Writers, Femininity and Spirituality in World Literature. Stockholm: Stockholm University Press (under review).

Uzoh, Gertrude

2012 One Love, Many Tears: It Takes Two to Tango, Bloomington, IN: AuthorHouse.

Winther, Tanja, and Harold Wilhite

2015 "Tentacles of Modernity: Why Electricity Needs Anthropology." Cultural WReC Anthropology 30(4):569-577.

2015 Combined and Uneven Development: Towards a New Theory of World-Literature. Liverpool: Liverpool University Press.

Wulff, Helena

2017 Rhythms of Writing: An Anthropology of Irish Literature. London: Bloomsbury. 